\title{
Tidal controls on trace gas dynamics in a seagrass meadow of the Ria Formosa lagoon (southern Portugal)
}

\author{
E. Bahlmann ${ }^{1}$, I. Weinberg ${ }^{1}$, J. V. Lavrič ${ }^{2}$, T. Eckhardt ${ }^{1}$, W. Michaelis ${ }^{1}$, R. Santos ${ }^{3}$, and R. Seifert ${ }^{1}$ \\ ${ }^{1}$ University of Hamburg, Institute for Biogeochemistry and Marine Chemistry, Bundesstraße 55, 20146 Hamburg, Germany \\ ${ }^{2}$ Max Planck Institute for Biogeochemistry, Hans-Knoell Str 10, 07745 Jena, Germany \\ ${ }^{3}$ Centro de ciências do mar, Universidade do Algarve, Gambelas, 8005-139 Faro, Portugal \\ Correspondence to: E. Bahlmann (enno.bahlmann@zmaw.de)
}

Received: 1 May 2014 - Published in Biogeosciences Discuss.: 10 July 2014

Revised: 2 February 2015 - Accepted: 23 February 2015 - Published: 17 March 2015

\begin{abstract}
Coastal zones are important source regions for a variety of trace gases, including halocarbons and sulfurbearing species. While salt marshes, macroalgae and phytoplankton communities have been intensively studied, little is known about trace gas fluxes in seagrass meadows. Here we report results of a newly developed dynamic flux chamber system that can be deployed in intertidal areas over full tidal cycles allowing for highly time-resolved measurements. The fluxes of $\mathrm{CO}_{2}$, methane $\left(\mathrm{CH}_{4}\right)$ and a range of volatile organic compounds (VOCs) showed a complex dynamic mediated by tide and light. In contrast to most previous studies, our data indicate significantly enhanced fluxes during tidal immersion relative to periods of air exposure. Short emission peaks occurred with onset of the feeder current at the sampling site.

We suggest an overall strong effect of advective transport processes to explain the elevated fluxes during tidal immersion. Many emission estimates from tidally influenced coastal areas still rely on measurements carried out during low tide only. Hence, our results may have significant implications for budgeting trace gases in coastal areas. This dynamic flux chamber system provides intensive time series data of community respiration (at night) and net community production (during the day) of shallow coastal systems.
\end{abstract}

\section{Introduction}

Coastal zones are important sites for carbon turnover and hotspots for a variety of volatile organic compounds (VOCs), including halogenated compounds (Gschwend et al., 1985; Moore et al., 1995; Baker et al., 1999; Rhew et al., 2000;
Christoph et al., 2002; Manley et al., 2006; Valtanen et al., 2009) and sulfur-bearing compounds (Dacey et al., 1987; Cooper et al., 1987a, b; De Mello et al., 1987; Turner et al., 1989; Leck and Rhode, 1990; Baker et al., 1992) but a minor source of hydrocarbons such as $\mathrm{CH}_{4}$ (Van der Nat and Middelburg, 2000; Middelburg et al., 2002). While coastal ecosystems, such as salt marshes, macroalgae and phytoplankton communities have been intensively studied, little is known about trace gas fluxes from seagrass meadows. Seagrass meadows are amongst the most productive coastal ecosystems, with an average net primary production of $817 \mathrm{~g} \mathrm{C} \mathrm{m}^{-2} \mathrm{yr}^{-1}$ (Mateo et al., 2006). They cover a considerable portion of global coastal zones with estimates ranging from 300000 (Duarte et al., 2005) to $600000 \mathrm{~km}^{2}$ (Mateo et al., 2006). Most previous studies of seagrass meadows have focused on carbon dynamics (e.g. Migné et al., 2004; Davoult et al., 2004; Spilmont et al., 2005; Silva et al., 2005; Hubas et al., 2006) and were often restricted to periods of air exposure. More recently, benthic chambers for underwater incubations have been developed (Nicholson et al., 1999; Larned, 2003; Barron et al., 2006; Silva et al., 2008; Ferron et al., 2009). There is some evidence that seagrass meadows (Zostera ssp.) are capable of forming a variety of trace gases (Urhahn, 2003; Weinberg et al., 2013). Like other higher plants rooting in anoxic soils and sediments, seagrasses have aerenchymatic tissue for supplying oxygen to their root system. This aerenchymatic tissue may also provide an effective transport pathway for trace gases from the sediment to the atmosphere (Armstrong, 1979; Larkum et al., 1989). The importance of this transport pathway has been shown for $\mathrm{CH}_{4}$ emissions from a variety of vegetation types (Laanbroek, 
2010). However, early incubation experiments have indicated fairly low emission rates from Thalassia testudinum beds (Oremland et al., 1975). More recently Deborde et al. (2010) reported $\mathrm{CH}_{4}$ fluxes from $\mathrm{Z}$. noltii meadows in the Arcachon lagoon (SW France) being below $1.6 \mu \mathrm{mol} \mathrm{m}^{-2} \mathrm{~h}^{-1}$, which was the detection limit of the instrumentation used for the experiment.

So far, the fluxes of trace gases in coastal environments, mainly $\mathrm{CH}_{4}$ and $\mathrm{CO}_{2}$, have been measured in most cases using static chambers (e.g. Van der Nat and Middelburg, 2000; Delaune et al., 1983; Bartlett et al., 1987; Migneé et al., 2002, 2004; Davoult et al., 2004; Spilmont et al., 2005; Silva et al., 2005; Hubas et al., 2006). There are several problems arising from chamber-based flux measurements that require a careful testing of the chamber system. Problems may arise under aerial conditions from perturbations of turbulence in the air and in the water-filled chamber spaces, the introduction of artificial gradients, perturbations of the thermal environment of the chamber and the gas composition inside the chamber (Gao et al., 1997; Meixner et al., 1997; Gao and Yates, 1998; Zhang et al., 2002; Pape et al., 2009). In particular, deposition fluxes of reactive trace gases are very sensitive to the aerodynamic properties of the chamber (Meixner et al., 1997; Pape et al., 2008). In contrast, the emission fluxes of most VOCs are insensitive against the turbulent conditions inside the chamber. The reason is that their production is independent of the headspace concentration (Pape et al., 2008).

Solid static chambers will most likely introduce stagnant conditions under submersed conditions and thus reduce the diffusive exchange and suppress advective exchange (Cook et al., 2007). This has, for instance, been shown for oxygen (Billerbeck et al., 2006; Werner et al., 2006; Kim and Kim, 2007; Cook et al., 2007; Jansen et al., 2009), total inorganic carbon (Cook et al., 2007) and dissolved organic matter (Huettel et al., 1997). Tengberg et al. (2004) compared three different types of stirred benthic chambers and found no significant differences between these chambers. The authors concluded that benthic chambers are insensitive to the hydrodynamic conditions as long as the water is well mixed and the sediment is not re-suspended.

In this study we used a modified dynamic chamber allowing flux measurements over full tidal cycles. The chamber is continuously purged during tidal immersion, whereby the purging introduces a turbulent flow inside the chamber. Though artificial, this turbulent motion inside the chamber may to some extent mimic the turbulent flow outside the chamber. The system allows continuous $\mathrm{CH}_{4}$ and $\mathrm{CO}_{2}$ flux measurements with a time resolution of $15 \mathrm{~min}$ as well as the determination of VOC fluxes by discrete sampling. Here we provide a detailed description of the flux chamber system and first results of a field study conducted in a seagrass meadow of the Ria Formosa lagoon, southern Portugal. We report tidal-cycle fluxes of $\mathrm{CO}_{2}, \mathrm{CH}_{4}$, propene, chloromethane $\left(\mathrm{CH}_{3} \mathrm{Cl}\right)$, bromomethane $\left(\mathrm{CH}_{3} \mathrm{Br}\right)$, iodomethane $\left(\mathrm{CH}_{3} \mathrm{I}\right)$, chloroform $\left(\mathrm{CHCl}_{3}\right)$, bromoform $\left(\mathrm{CHBr}_{3}\right)$ and carbon disul- fide $\left(\mathrm{CS}_{2}\right)$ and discuss them in terms of the factors controlling trace gas dynamics in intertidal seagrass meadows.

\section{Methods}

\subsection{Flux chamber design}

Dynamic flux chambers have been widely used in trace gas studies of terrestrial systems (Gao et al., 1997; Gao and Yates, 1998; Kim and Lindberg, 1995; Zhang et al., 2002; Pape et al., 2009). Details on the theory of dynamic flux chamber measurements are given in Gao et al. (1997) and Meixner et al. (1997). Briefly, the surface of interest is enclosed within a chamber and air is pumped through the chamber at a predefined flow rate. Net fluxes above the covered surface are commonly calculated from the concentration difference between the outlet and inlet of the chamber.

$F_{\mathrm{Net}}=\frac{Q_{\mathrm{N}} \times\left(C_{\mathrm{out}}-C_{\mathrm{in}}\right)}{A \times V_{\mathrm{N}} \times 1000}$,

where $F_{\text {Net }}$ is the net flux [mol m${ }^{-2} \mathrm{~h}^{-1}$ ], $Q_{\mathrm{N}}$ is the flushing flow rate through the chamber $\left[\mathrm{m}^{3} \mathrm{~h}^{-1}\right.$, at $1013.25 \mathrm{mbar}$ and $298.15 \mathrm{~K}], C_{\text {out }}$ and $C_{\text {in }}$ are the air mixing ratios of target compounds [mole fractions] at the outlet and the inlet of the flux chamber, respectively, $A$ is the bottom surface area of the flux chamber $\left[\mathrm{m}^{2}\right]$, and $V_{\mathrm{N}}$ is the molar volume $\left[\mathrm{m}^{3}\right]$ at 1013.25 mbar and $298.15 \mathrm{~K}$. Note that emission fluxes are positive.

The chamber we used was made from a $10 \mathrm{~L}$ Duran glass bottle with the bottom cut off (Fig. 1). The chamber had a volume of $8 \mathrm{~L}$, a bottom surface area of $0.037 \mathrm{~m}^{2}$, and a height of $0.3 \mathrm{~m}$. The chamber is pressed $5 \mathrm{~cm}$ into the sediment prior to sampling, resulting in a headspace volume of approximately $6 \mathrm{~L}$. Water enters and leaves the chamber through a U-tube at the bottom during tidal change (stainless steel tube $50 \mathrm{~cm}$ length, $4 \mathrm{~mm}$ i.d.). The tube was connected to a valve that was closed during air exposure and open during tidal immersion. Ambient air is pumped through the chamber with a membrane pump (KNF-Neuberger, Germany, model N86KNDC) at a flow rate between 3.0 and $3.5 \mathrm{~L} \mathrm{~min}^{-1}$. The air enters the chamber through a PFA tube at the top of the chamber and is further distributed to two metal frits $(10 \mu \mathrm{m}$ pore size). The frits are placed $12 \mathrm{~cm}$ above the sediment surface preventing visible dispersion of surface sediments. The outlet of the chamber is connected to an open split in $2.5 \mathrm{~m}$ height via a $1 / 2$ in. o.d. PFA tube. The tube is inserted $30 \mathrm{~cm}$ into a stainless steel tube $(50 \mathrm{~cm}$ long, $3 / 4$ in. o.d.) that is open at the bottom and has two sampling ports at the top. Typically, about $0.5 \mathrm{~L} \mathrm{~min}^{-1}$ is directed to the $\mathrm{CO}_{2} / \mathrm{CH}_{4}$ analyser and $1.5 \mathrm{~L} \mathrm{~min}^{-1}$ is directed to the trace gas sampling system. The excess air, along with water droplets and aerosols, is vented into the atmosphere via the open split. Two Teflon ${ }^{\circledR}$ membrane filters are used to further protect the sampling systems from water and aerosols. 


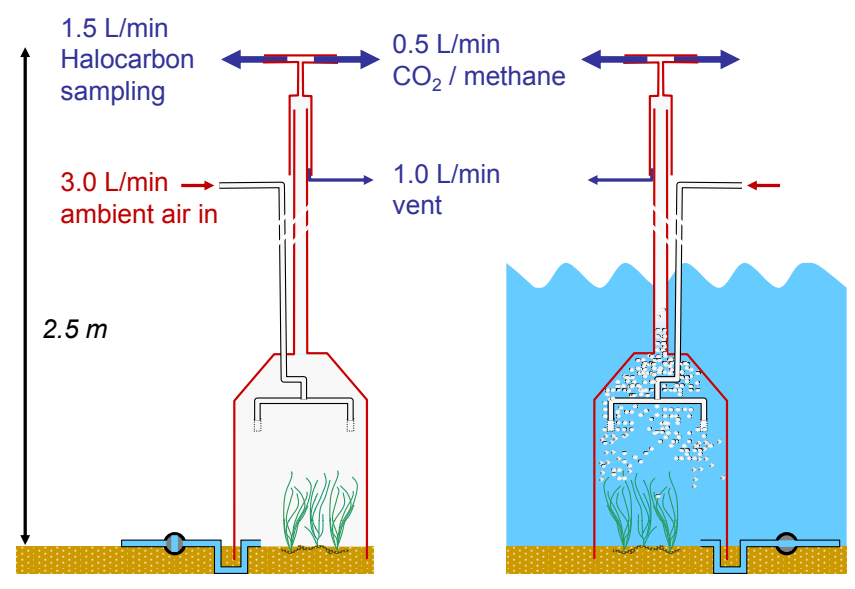

Figure 1. Scheme of the dynamic flux chamber system. During air exposure the chamber acts as a conventional dynamic flux chamber. During tidal immersion the enclosed water is continuously purged with ambient air.

The U-tube at the bottom and the open split ensured pressure equilibrium between the chamber and the ambient water body. The performance of the chamber was tested under aerial and submersed conditions in the laboratory. A detailed description of these tests is given in the supplementary material. The response time of the chamber is 2 min under aerial conditions at a flushing flow rate of $3 \mathrm{~L} \mathrm{~min}^{-1}$. Complete mixing of the chamber volume is achieved within $0.4 \mathrm{~min}$. Hence, with respect to our sampling frequency, we can safely assume complete mixing of the air inside the chamber.

The physical nature of trace gas fluxes across natural interfaces is commonly described in terms of a multiresistance model (Hicks et al., 1987). This model has been applied to flux chambers (Gao and Yates, 1987; Zhang et al., 2002; Pape et al., 2008):

$F_{\mathrm{i}}=\frac{c_{\mathrm{s}}-c_{\mathrm{a}}}{R_{\mathrm{c}}+R_{\mathrm{s}}}$,

where $F_{\mathrm{i}}$ denotes the flux across the interface, $c_{\mathrm{s}}$ is the concentration in the sediment, $c_{\mathrm{a}}$ is the gas concentration on the air side of the interface, $R_{\mathrm{c}}\left[\mathrm{tL}^{-1}\right]$ is the overall transfer resistance of the chamber system and $R_{\mathrm{S}}\left[\mathrm{tL}^{-1}\right]$ is the transfer resistance of the sediment surface layer $\left(R_{\mathrm{S}}\right)$. While $R_{\mathrm{c}}$ is dependent on the aerodynamic properties of the chamber, $R_{\mathrm{S}}$ is dependent on the sediment properties. The sensitivity of the overall flux against the aerodynamic properties depends on the magnitude of $R_{\mathrm{c}}$ and $R_{\mathrm{s}}$. When both share the same magnitude, the flux across the interface depends on $R_{\mathrm{c}}$ and $R_{\mathrm{S}}$. On the other hand, when $R_{\mathrm{S}}$ becomes large relative to $R_{\mathrm{C}}$, the flux is mainly governed by $R_{\mathrm{S}}$ (Zhang et al., 2002). The chamber tests revealed an upper limit of $0.162 \mathrm{~h} \mathrm{~m}^{-1}$ for the aerodynamic transfer resistance of the chamber. The sediment side transfer resistance was estimated from the diffusivity of the sediment surface layer and its thickness (Gao, 1986; Zhang et al., 2002). $R_{\mathrm{S}}$ ranges from 1.54 to $15.4 \mathrm{~h} \mathrm{~m}^{-1}$ for waterlogged intertidal sediments with an air-filled pore space from 1 to $10 \%$. The transfer resistance of the seagrass leaves was derived from the $\mathrm{CO}_{2}$ permeability of the cuticula of submersed plants (MacFarlane, 1992) and the leaf area index of Z. noltii in the Ria Formosa (Pérez-Lloréns and Niell, 1993). It was estimated to range from 26.5 to $46 \mathrm{~h} \mathrm{~m}^{-1}$, thus being 1 to 2 orders of magnitude larger than $R_{\mathrm{c}}$. Given this, it is reasonable to assume that, during air exposure, the gas exchange across the sediment surface and the seagrass leaves is not dependent on the aerodynamic properties of the chamber. Further, our tests suggest a minor effect of the flushing flow rate on the atmospheric transfer resistance, making the overall transfer resistance insensitive to the aerodynamic properties of the chamber.

The interfacial fluxes are insensitive to the hydrodynamic conditions in the chamber during submersion as long as the water inside the chamber is well mixed and the sediment is not re-suspended. Re-suspension of the sediments was avoided during the experiments and was checked visibly. The gas flow through the chamber introduced a water flow of the order of 10 to $15 \mathrm{~cm} \mathrm{~s}^{-1}$, providing a corresponding boundary layer thickness in the range of 60 to $120 \mu \mathrm{m}$ where the carbon uptake is mainly enzymatically limited. The visible inferred mixing time was in $1.1 \mathrm{~min}$. Under submersed conditions the dissolved trace gases are equilibrated with ambient air. The flux and thus the response time will depend on the volatility (given by the Henry's law constant) and the waterair transfer resistance of the chamber system. In analogy to the air-sea gas exchange the air-water gas exchange can be computed as

$F=k_{\mathrm{c}} \times\left(c_{\mathrm{w}} / H-c_{\mathrm{g}}\right)=\frac{\left(c_{\mathrm{w}} / H-c_{\mathrm{g}}\right)}{R_{\mathrm{c}}}$,

where $k_{\mathrm{c}}$ is the specific gas exchange velocity $\left[\mathrm{Lt}^{-1}\right]$ of the chamber. $K_{\mathrm{c}}$ depends on the flushing flow rate $(Q)$ and the chamber design (in particular the chamber geometry and the gas bubble geometry), $R_{\mathrm{c}}=1 / k_{\mathrm{c}}$ is the corresponding transfer resistance, $c_{\mathrm{W}}$ is the water concentration $\left[\mathrm{mol} \mathrm{L}^{-3}\right], c_{\mathrm{g}}$ is the concentration in the gas phase inside the chamber, and $H$ is the Henry's law constant.

The response time of the chamber towards changes in the $p \mathrm{CH}_{4}$ was $1.20 \pm 0.20 \mathrm{~min}$. The response time for DIC (dissolved inorganic carbon) depends on the carbon speciation. It ranged from 10 to $58 \mathrm{~min}$ for a $\triangle \mathrm{DIC}$ ranging from 188 to $-203 \mu \mathrm{mol} \mathrm{kg}-1$, reflecting the changing ratio of dissolved $\mathrm{CO}_{2}$ to DIC. Here $\triangle \mathrm{DIC}$ refers to the deviation of the DIC concentration from equilibrium with the inlet air. Equilibrium conditions during the tests were a DIC of $1960 \pm 15 \mu \mathrm{mol} \mathrm{kg}^{-1}$, an alkalinity of $2180 \pm 15 \mu \mathrm{eg} \mathrm{kg}-1$ and a $p \mathrm{CO}_{2}$ of $425 \pm 10 \mathrm{ppm}$ at $296.5 \mathrm{~K}$.

The U-tube at the bottom of the chamber inevitably leads to an exchange of water between the chamber and the surrounding water body that may affect the flux measurements. The water exchange was not metered on-site. From the Hagen-Poiseuille law we estimated a response time towards 
water exchange of $2.15 \pm 0.15 \mathrm{~h}$. This is substantially larger than the respective response times for the gas exchange. For $\mathrm{CH}_{4}$ we can safely assume that the bias due to water exchange is regardless of the concentration difference between the chamber and the surrounding water less than $1 \%$. Due to the much slower response time, the bias with respect to DIC becomes larger.

We assumed a constant source or sink inside the chamber and an incubation time of $6 \mathrm{~h}$ for a first estimate of the bias. Under these conditions the recovery for a $\mathrm{CO}_{2}$ sink ranges from 69 to $75 \%$ and the recovery for a $\mathrm{CO}_{2}$ source ranges from 78 to $83 \%$, with both depending on the source/sink strength. We found these recoveries acceptable for a first tentative assessment of the DIC dynamics over full tidal cycles, as was the primary goal of our study.

\subsection{Sampling site}

The sampling was conducted in an intertidal seagrass meadow of Zostera noltii (Hornemann) of Ria Formosa lagoon, a mesotidal system located in southern Portugal. The lagoon has a surface area of $84 \mathrm{~km}^{2}$, with about $80 \%$ of it being intertidal. It is separated from the open ocean by a system of sand barrier islands. Six inlets allow exchanges of water with the Atlantic Ocean. The tidal amplitude ranges from $3.50 \mathrm{~m}$ on spring tides to $1.30 \mathrm{~m}$ on neap tides. In each tidal cycle about 50 to $75 \%$ of the water in the lagoon is renewed. Except during sporadic periods of heavy rainfall, salinity ranges from 35.5 to 36.0 PSU throughout the year; water temperature varies between 12 and $27^{\circ} \mathrm{C}$ in winter and summer, respectively.

Z. noltii is the most abundant seagrass species in the Ria Formosa, covering about $45 \%$ of the intertidal area (Guimarães et al., 2012). The species plays a major role in the whole ecosystem metabolism of the lagoon (Santos et al., 2004). The range of $Z$. noltii biomass variation at the sampling site is $229-310 \mathrm{~g} \mathrm{DW} \mathrm{m}^{-2}$ (Cabaço et al., 2008).

\subsection{Sampling and measurement}

The $\mathrm{CO}_{2}$ and $\mathrm{CH}_{4}$ flux measurements were performed between 23 April and 27 April 2012. VOC fluxes were measured between 17 April and 28 April 2012. Therefore, the time base of the VOC sampling does not fully overlap the time base of the $\mathrm{CO}_{2}$ and $\mathrm{CH}_{4}$ sampling. The sampled seagrass patches (Z. noltii) were free of visible epiphytes and macroalgae. The canopy coverage was estimated to be higher than $95 \%$.

$\mathrm{CO}_{2}$ and $\mathrm{CH}_{4}$ were measured on-site with a Picarro 1301 cavity ring-down spectrometer. A six-port Valco valve was used to switch between three different sampling lines. The first sampling line was directly connected to the dynamic flux chamber, and the two other sampling lines were used to sample ambient air from two different heights above the ground ( 2 and $4 \mathrm{~m})$. The sampling lines were consecutively sampled for $5 \mathrm{~min}$ and each line was connected to an additional membrane pump for continuously flushing at a flow rate of $0.5 \mathrm{~L} \mathrm{~min}^{-1}$ when not sampled. The sampling order was height 1 , height 2 , chamber. The mixing ratios from the two air sampling lines were averaged to calculate the inlet concentration of the chamber. Discrete gas samples were taken from the second sampling port of the flux chamber to determine the outlet concentration of the VOCs. In parallel, discrete samples were taken from the feeding line to the flux chamber via a T-union to determine the inlet concentration of the VOCs. Details of the VOC sampling system are given in Weinberg et al. (2015). Briefly, $30 \pm 5 \mathrm{~L}$ of ambient air was drawn through a cryo-trap at a flow rate of $1.0 \pm 0.2 \mathrm{~L} \mathrm{~min}^{-1}$. The samples were thermally desorbed from the cryo-trap $\left(310^{\circ} \mathrm{C}\right)$ using a flow of helium $\left(30 \mathrm{~mL} \mathrm{~min}^{-1}\right.$ for $\left.15 \mathrm{~min}\right)$ and recollected on Peltier-cooled adsorption tubes maintained at $-10^{\circ} \mathrm{C}$. From the adsorption tube the samples were again desorbed into a flow of helium and refocused on a quartz capillary $(0.32 \mathrm{~mm}$ i.d., $60 \mathrm{~cm}$ length) immersed in liquid nitrogen. The analytes were desorbed from the quartz capillary at ambient temperature and transferred to a GC-MS system (6890N/5975B, Agilent). VOCs were separated on a CP-PoraBOND Q column (Varian, $25 \mathrm{~m}, 0.25 \mu \mathrm{m}$ i.d.) with helium as a carrier gas. Quantification of $\mathrm{CH}_{3} \mathrm{Cl}, \mathrm{CH}_{3} \mathrm{Br}, \mathrm{CH}_{3} \mathrm{I}, \mathrm{CHCl}_{3}, \mathrm{CHBr}_{3}$, propene and $\mathrm{CS}_{2}$ was performed against a Scott TOC 15/17 standard containing these compounds among others at $1 \mathrm{ppm}$ each in nitrogen. Typically two to four aliquots of $1 \mathrm{~mL}$ were analysed each day. The overall precision of this method is better than $\pm 6 \%$.

\section{Results}

The high time resolution of our measurements provided detailed insights into the complex dynamics of $\mathrm{CH}_{4}$ and $\mathrm{CO}_{2}$ fluxes in the intertidal of the Ria Formosa. The flux patterns of $\mathrm{CO}_{2}$ and $\mathrm{CH}_{4}$ of both $\mathrm{Z}$. noltii and adjacent bare sediment patches are shown in Figs. 2 and 3, respectively. Table 1 provides the time-averaged fluxes for different stages of the tidal cycle. In general, much higher $\mathrm{CO}_{2}$ and $\mathrm{CH}_{4}$ fluxes were observed for the seagrass-covered areas than for the bare sediment. The fluxes of both gases showed clear diurnal variations with similar patterns above the seagrass and the bare sediment. We observed a strong influence of the tidal cycle on fluxes of both gases, with more pronounced emission fluxes generally occurring during tidal inundation. During daytime, $\mathrm{CO}_{2}$ assimilation dominated over benthic respiration, resulting in a net uptake, regardless of the tidal state. Elevated fluxes during tidal immersion were also observed for all non- $\mathrm{CH}_{4}$ VOCs studied here. 


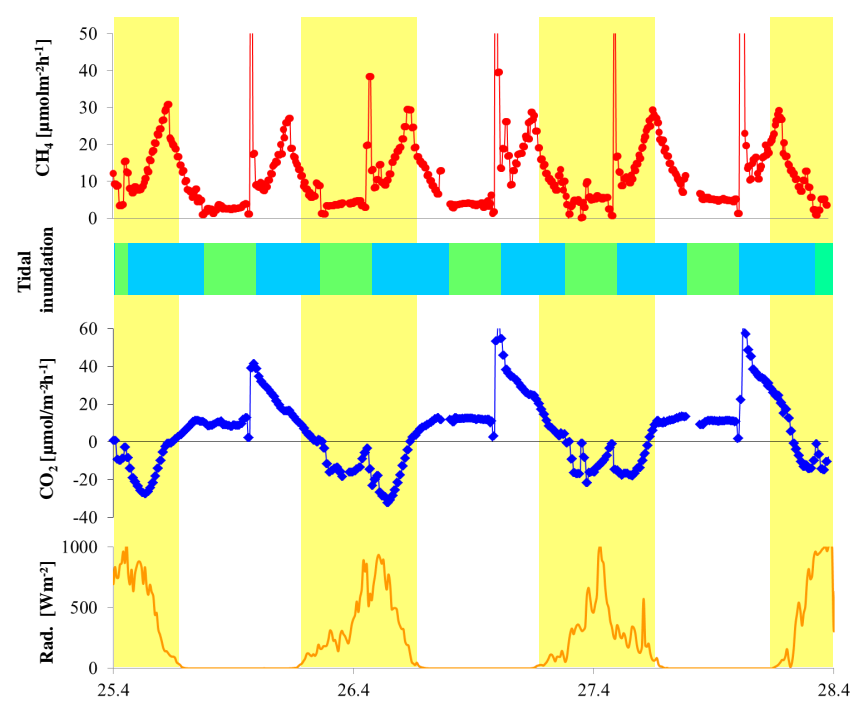

Figure 2. Diurnal variations of the $\mathrm{CH}_{4}$ and $\mathrm{CO}_{2}$ fluxes above a meadow of the seagrass $Z$. noltii. Light intensity is also shown. The measurements were carried out from 25 to 28 April 2012. Yellow bars indicate daylight periods, green bars indicate periods of air exposure, and blue bars indicate periods of tidal immersion.

\subsection{Methane}

During air exposure at low tide, $\mathrm{CH}_{4}$ fluxes averaged $4.4 \mu \mathrm{mol} \mathrm{m}{ }^{-2} \mathrm{~h}^{-1}$ during night-time and $6.9 \mu \mathrm{mol} \mathrm{m}^{-2} \mathrm{~h}^{-1}$ during daytime. With the flood current just arriving at the sampling site, the fluxes dropped almost to zero for $>15 \mathrm{~min}$. A sharp emission peak was observed for $15 \mathrm{~min}$ following this drop. Accounting for the integration time and the response time of the chamber system, we deduce that these events may have actually lasted for 2 to $5 \mathrm{~min}$. The fluxes averaged $71 \mu \mathrm{mol} \mathrm{m}{ }^{-2} \mathrm{~h}^{-1}$ during these peak events. The peaks were more pronounced during the night (76 and $123 \mu \mathrm{mol} \mathrm{m}^{-2} \mathrm{~h}^{-1}$ ) than during daytime (38 and $51 \mu \mathrm{mol} \mathrm{m} \mathrm{m}^{-2} \mathrm{~h}^{-1}$ ). The fluxes rapidly decreased after the peak events to values below $9 \pm 1 \mu \mathrm{mol} \mathrm{m} \mathrm{m}^{-2} \mathrm{~h}^{-1}$.

During tidal immersion, the $\mathrm{CH}_{4}$ fluxes increased with rising height of the water and showed a second maximum of $30 \pm 1 \mu \mathrm{mol} \mathrm{m}^{-2} \mathrm{~h}^{-1}$ at high tide. The $\mathrm{CH}_{4}$ fluxes decreased constantly with the ebb flow to values about $9 \pm 1 \mu \mathrm{mol} \mathrm{m}{ }^{-2} \mathrm{~h}^{-1}$ at water levels below $10 \mathrm{~cm}$. The change from tidal immersion to air exposure was marked by slightly elevated fluxes observed for about $15 \mathrm{~min}$, followed by a drop close to zero before the flux stabilized at the low-tide level again.

The diurnal flux cycles observed above the sediment (Fig. 3) were similar to those above the seagrass but with much lower values (Table 1 and Fig. 2). The $\mathrm{CH}_{4}$ fluxes averaged $0.3 \mu \mathrm{mol} \mathrm{m} \mathrm{m}^{-2} \mathrm{~h}^{-1}$ during low tide, and $6 \mu \mathrm{mol} \mathrm{m}^{-2} \mathrm{~h}^{-1}$ $\left(5.2 \mu \mathrm{mol} \mathrm{m}{ }^{-2} \mathrm{~h}^{-1}\right.$ during daytime and $6.6 \mu \mathrm{mol} \mathrm{m}^{-2} \mathrm{~h}^{-1}$ during night-time) during tidal inundation.

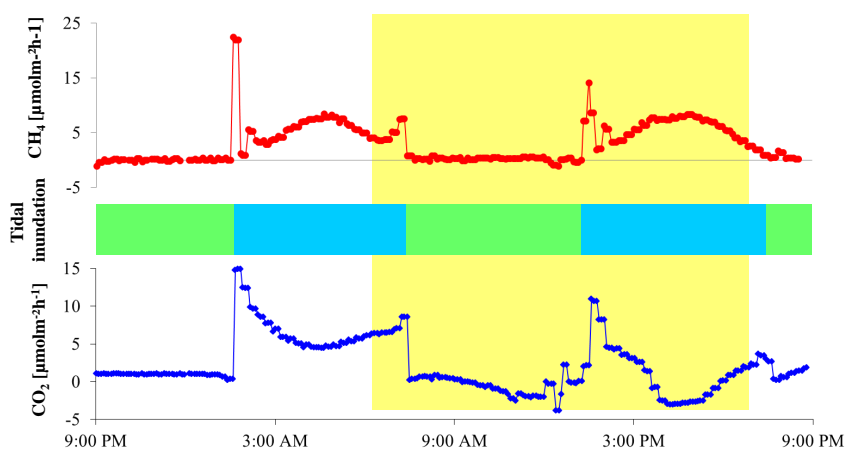

Figure 3. $\mathrm{CH}_{4}$ and $\mathrm{CO}_{2}$ fluxes above a bare sediment patch recorded on 23 April 2012. The upper graph in red shows the $\mathrm{CH}_{4}$ fluxes in $\mu \mathrm{mol} \mathrm{m}-2 \mathrm{~h}^{-1}$ and the lower graph show the $\mathrm{CO}_{2}$ fluxes in $\mathrm{mmol} \mathrm{m} \mathrm{m}^{-2} \mathrm{~h}^{-1}$. The yellow bar indicates daylight periods, green bars indicate periods of air exposure, and blue bars indicate periods of tidal immersion.

Table 1. Averaged $\mathrm{CO}_{2}$ and $\mathrm{CH}_{4}$ fluxes above seagrass for different periods of the tidal cycle. The fluxes were calculated from the measurements of day 2 and 3. By definition, emission fluxes are positive and deposition fluxes are negative.

\begin{tabular}{lrrrr}
\hline Tidal stage & $\mathrm{CO}_{2}\left(\mathrm{mmol} \mathrm{m}^{-2} \mathrm{~h}^{-1}\right)$ & $\mathrm{CH}_{4}\left(\mu \mathrm{mol} \mathrm{m}{ }^{-2} \mathrm{~h}^{-1}\right)$ \\
\hline & Sediment & Seagrass & Sediment & Seagrass \\
Air exposure (day) & -1.1 & -9.1 & 0.4 & 6.9 \\
Air exposure (night) & 1.0 & 8.4 & 0.2 & 4.4 \\
Tidal inundation (day) & -2.0 & -16.4 & 6.6 & 14.3 \\
Tidal inundation (night) & 6.4 & 20.1 & 5.2 & 16.6 \\
Peak (water just arriving) & 14.8 & 55.0 & 10.8 & 71.0 \\
\hline Mean (time-averaged) & 2.1 & 4.2 & 3.0 & 12.8 \\
\hline
\end{tabular}

\section{$3.2 \mathrm{CO}_{2}$}

In contrast to $\mathrm{CH}_{4}$, the $\mathrm{CO}_{2}$ flux was strongly influenced by both the time of day and the tidal cycle. Deposition fluxes were observed during the day, resulting from photosynthetic carbon uptake, while positive fluxes were observed during the night due to respiratory release of $\mathrm{CO}_{2}$. The emissions were relatively constant during air exposure at night and averaged $8.4 \pm 0.5 \mathrm{mmol} \mathrm{m}^{-2} \mathrm{~h}^{-1}$. As observed for $\mathrm{CH}_{4}$, the flux dropped to zero for about $10 \mathrm{~min}$ with the incoming tide and then rapidly increased to highest $\mathrm{CO}_{2}$ emissions of up to $62 \mathrm{mmol} \mathrm{m}^{-2} \mathrm{~h}^{-1}$. Thereafter, the $\mathrm{CO}_{2}$ flux decreased rapidly to $38 \pm 4 \mathrm{mmol} \mathrm{m}^{-2} \mathrm{~h}^{-1}$ and then further declined slowly over the period of tidal inundation. After sunrise, roughly coinciding with high tide during our measurements, the $\mathrm{CO}_{2}$ fluxes declined more rapidly due to the beginning of photosynthetic $\mathrm{CO}_{2}$ assimilation. $\mathrm{CO}_{2}$ assimilation dominated over benthic $\mathrm{CO}_{2}$ respiration during the daylight period resulting in a net uptake of $\mathrm{CO}_{2}$ with average fluxes of $-9.1 \mathrm{mmol} \mathrm{m}^{-2} \mathrm{~h}^{-1}$ during air exposure and $-16.4 \mathrm{mmol} \mathrm{m}^{-2} \mathrm{~h}^{-1}$ during immersion.

At night, the average sedimentary $\mathrm{CO}_{2}$ fluxes were $1.0 \mathrm{mmol} \mathrm{m}^{-2} \mathrm{~h}^{-1}$ during air exposure and $6.4 \mathrm{mmol} \mathrm{m} \mathrm{m}^{-2}$ 


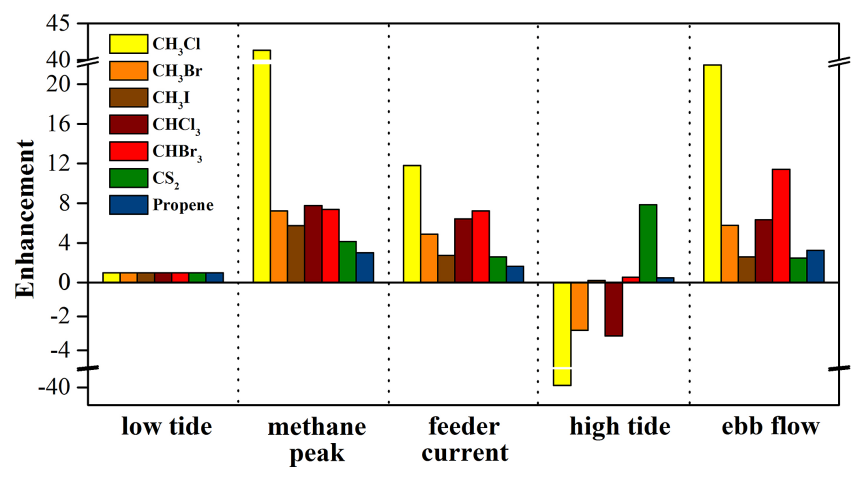

Figure 4. Relative enhancement of selected VOC fluxes from a tidally influenced seagrass bed. All fluxes were normalized to the respective mean fluxes during low tide. Mean and ranges are provided in Table 2.

$\mathrm{h}^{-1}$ during tidal inundation. The $\mathrm{CO}_{2}$ night-time flux during inundation decreased until high tide and increased again with the onset of ebb flow, indicating an inverse relation to the height of the water table. The daytime average $\mathrm{CO}_{2}$ fluxes from sediment were $-1 \mathrm{mmol} \mathrm{m}^{-2} \mathrm{~h}^{-1}$ during low tide and $-2 \mathrm{mmol} \mathrm{m}^{-2} \mathrm{~h}^{-1}$ during tidal inundation.

\subsection{VOCs}

Relative fluxes of $\mathrm{CS}_{2}, \mathrm{CH}_{3} \mathrm{Cl}, \mathrm{CH}_{3} \mathrm{Br}, \mathrm{CH}_{3} \mathrm{I}, \mathrm{CHCl}_{3}$, $\mathrm{CHBr}_{3}$ and propene are shown in Fig. 4. Mean fluxes and ranges are provided in Table 2. It should be noted that, for most of the VOC flux data, the sampling time does not coincide with the sampling time for the $\mathrm{CO}_{2}$ and $\mathrm{CH}_{4}$ data shown above. As observed for $\mathrm{CO}_{2}$ and $\mathrm{CH}_{4}$, the emission rates during tidal immersion significantly exceeded those measured during air exposure. The average enhancement during tidal immersion (relative to the average fluxes during air exposure) ranged from 4 to 12 for $\mathrm{CS}_{2}, \mathrm{CH}_{3} \mathrm{Br}, \mathrm{CH}_{3} \mathrm{I} \mathrm{CHCl}_{3}$ and $\mathrm{CHBr}_{3}$. A higher enhancement was observed for $\mathrm{CH}_{3} \mathrm{Cl}$. A less pronounced enhancement ranging from 1 to 3 was observed for propene. Among the analysed VOCs, only $\mathrm{CH}_{3} \mathrm{Cl}$ fluxes increase similarly drastically to those of $\mathrm{CH}_{4}$ with the feeder current arriving at the sampling site. In this context it is important to note that the sampling time for the VOCs was $30 \mathrm{~min}$ followed by a break of $15 \mathrm{~min}$ required to change the cryo-traps. Hence, it is possible that peak flux, lasting 3$5 \mathrm{~min}$ for $\mathrm{CH}_{4}$, is missed or not fully captured by our VOC sampling protocol. For $\mathrm{CHBr}_{3}$ our data also show a small enhancement when the water just starts receding from the sampling site.

The temporal flux patterns show some remarkable differences between individual VOCs during tidal immersion. Strongly enhanced fluxes during high tide were observed for $\mathrm{CS}_{2}$, showing a similar pattern to that observed for $\mathrm{CH}_{4}$. The fluxes of the other monitored compounds decreased or even turned from emission to uptake during high tide and thus acted in a more similar manner to $\mathrm{CO}_{2}$.

\subsection{Atmospheric mixing ratios of $\mathrm{CO}_{2}$ and $\mathrm{CH}_{4}$}

The atmospheric mixing ratios of $\mathrm{CO}_{2}$ and $\mathrm{CH}_{4}$ are shown in Fig. 5. $\mathrm{CO}_{2}$ mixing ratios (both heights) ranged from 395.5 to $429.7 \mathrm{ppm}$ and averaged $400.3 \mathrm{ppm}$. The atmospheric mixing ratios of $\mathrm{CH}_{4}$ ranged from 1.831 to $1.895 \mathrm{ppm}$ (both heights) and averaged $1.861 \mathrm{ppm}$. Lowest mixing ratios of $395.8 \pm 0.2 \mathrm{ppm}$ for $\mathrm{CO}_{2}$ and of $1.834 \pm 0.004 \mathrm{ppm}$ for $\mathrm{CH}_{4}$ were observed between 20:00 UCT on 25 April and 04:00 on 26 April and coincided with westerly winds from the open ocean and wind speeds above $4 \mathrm{~m} \mathrm{~s}^{-1}$. With decreasing wind speeds and during easterly winds, when the air masses passed over large parts of the lagoon, the atmospheric mixing ratios of $\mathrm{CO}_{2}$ and $\mathrm{CH}_{4}$ increased.

The close coupling between the measured fluxes and the atmospheric mixing ratios at low wind speeds becomes particularly evident at the end of the campaign. The atmospheric mixing ratios of $\mathrm{CH}_{4}$ nicely resemble the enhanced emissions during immersion over the last two tidal cycles. The sharp methane emission peak observed when the water entered the chamber becomes diffuse under ambient conditions as bubble ebullition will occur throughout rising tide at the water line. This coupling is somewhat indistinct on 27 April because of rapidly changing wind conditions. Nevertheless, elevated $\mathrm{CH}_{4}$ mixing ratios coincide with elevated fluxes during tidal immersion. As for $\mathrm{CH}_{4}$, elevated mixing ratios of atmospheric $\mathrm{CO}_{2}$ coincide with periods of strong $\mathrm{CO}_{2}$ emissions during tidal immersion at night. Notably, on 26 April at noon, the atmospheric $\mathrm{CO}_{2}$ mixing ratios show a slight drop when carbon assimilation was largest. In summary, the pattern of the atmospheric mixing ratios supports the flux pattern observed within the chamber.

\section{Discussion}

\subsection{Temporal flux patterns}

The most striking feature of our results is the pronounced effect of the tidal cycle on the fluxes of all trace gases, which were significantly enhanced during immersion compared to air exposure periods. Additionally, strong emission peaks of $\mathrm{CH}_{4}$, among other VOCs, and particularly of $\mathrm{CO}_{2}$, occurred during a short transition period from air exposure to immersion.

We are aware of only one study reporting a positive correlation of $\mathrm{CO}_{2}$ and $\mathrm{CH}_{4}$ fluxes with the height of the water table from a brackish coastal lagoon in Japan (Yamamoto et al., 2009). The authors of this study did not come up with a conclusive explanation for this observation. They suggested lateral transport in the sediment in combination with salinity gradients affecting the source strength and/or enhanced gas ebullition due to increased pressure from the water column. The Ria Formosa lagoon has a negligible inflow of freshwater and a year-round salinity between 35 and 36 PSU. 

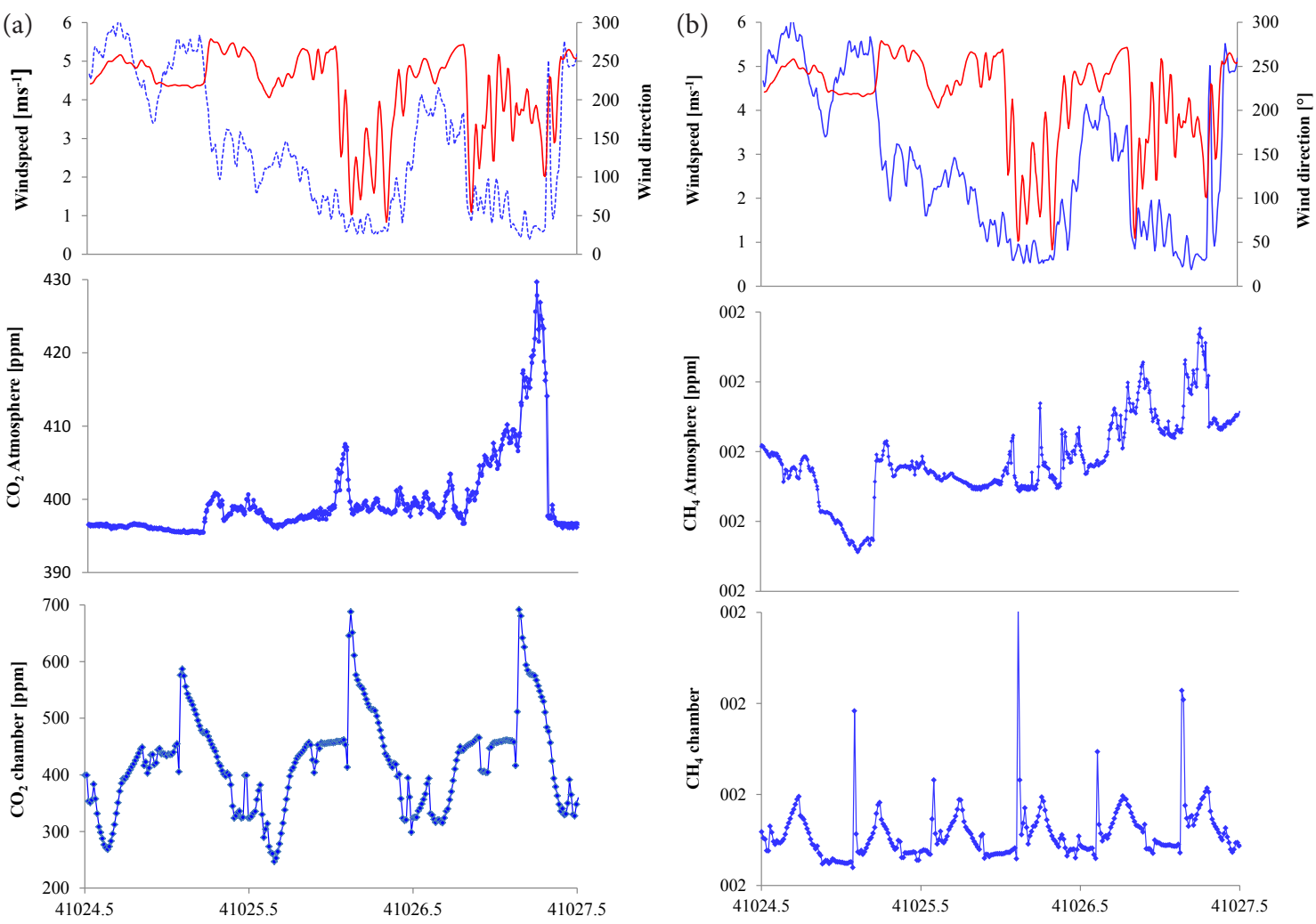

Figure 5. (a) Time series of $\mathrm{CO}_{2}$ mixing ratios at the chamber outlet and in the atmosphere along with meteorological conditions (20 min moving average). In the upper panel, the dashed blue line indicates the wind speed. (b) The same but for $\mathrm{CH}_{4}$.

This makes salinity-driven lateral changes in methanogenesis and benthic respiration implausible. Spatial variations in the source strength that might occur due to variations in the benthic communities and in the supply of substrate by litter production and root exudates are also not plausible, as the benthic vegetation around the sampling site consisted almost exclusively of $Z$. noltii and was quite homogeneous. Variations in the above-ground biomass were clearly below a factor of 2 and thus do not support a linear change in the source strength by a factor of 6 as observed for $\mathrm{CH}_{4}$ during tidal immersion. On the other hand, a negative relation between bubble ebullition and water pressure has been reported in other studies (Baird et al., 2004; Glaser et al., 2004), including the only study we are aware of that was carried out in a tidally influenced system (Chanton et al., 1989).

Most previous studies on trace gas fluxes in tidally influenced systems have reported higher fluxes during low tide than during high tide. These higher emissions during low tide were attributed to reduced gas diffusion during inundation (Heyer and Berger, 2000; Van der Nat and Middelburg, 2000) or to deep porewater circulation in tidal flats (Barnes et al., 2006; De La Paz et al., 2008; Grunwald et al., 2009; Deborde et al., 2010). Since the pioneering work of Riedl et al. (1972) there has been rising evidence that advective exchange processes at the sediment-water inter- face strongly affect the fluxes and concentrations of trace constituents. Billerbeck et al. (2006) proposed two different pathways for porewater circulation in intertidal sediments. The first pathway, called "body circulation", is generated by the hydraulic gradient between seawater and porewater levels in the sediment, and leads to seepage of porewater close to the low-water line at low tide. The second pathway, called "skin circulation", refers to the advective exchange in surface sediments and is driven by bottom-current-induced pressure gradients at the sediment surface. Several studies have shown a prominent effect of advective transport processes on the exchange of organic matter and nutrients in tidal sand flats (Werner et al., 2006; Billerbeck et al., 2006; Huettel et al., 1996; Precht et al., 2004). Werner et al. (2006) found a more intense and deeper transport of oxygen into the sediment due to advective exchange during tidal immersion than during air exposure, when the exchange is presumably driven by gas diffusion. This is also supported by a study of Kim and Kim (2007), who reported total oxygen fluxes exceeding diffusive fluxes by a factor of 2 to 3 for intertidal sediments from Teaean bay, located in the midwestern part of the Korean peninsula. Cook et al. (2007) reported a concurrent increase in total oxygen and TIC (total inorganic carbon) fluxes at the sediment surface by a factor of up to 2.5 under turbulent conditions relative to stagnant (diffusive) conditions. In 
Table 2. Mean trace gas fluxes (bold) obtained from seagrass meadows along the tidal cycle. Fluxes are given in $\mathrm{nmol} \mathrm{m}^{-2} \mathrm{~h}^{-1}$. Numbers in parentheses are the range of fluxes. Fluxes during high tide are given as single values. Further details on $\mathrm{CH}_{3} \mathrm{Cl}_{,} \mathrm{CH}_{3} \mathrm{Br}_{2} \mathrm{CH}_{3} \mathrm{I}$ and $\mathrm{CHBr}_{3}$ are given in Weinberg et al. (2015). By definition, emission fluxes are positive and deposition fluxes are negative.

\begin{tabular}{lrrrrr}
\hline Compound & $\begin{array}{r}\text { Low } \\
\text { tide } \\
(n=17)\end{array}$ & $\begin{array}{r}\mathrm{CH}_{4} \\
\text { peak } \\
(n=5)\end{array}$ & $\begin{array}{r}\text { Feeder } \\
\text { current } \\
(n=6)\end{array}$ & $\begin{array}{r}\text { High } \\
\text { tide } \\
(n=2)\end{array}$ & $\begin{array}{r}\text { Ebb } \\
\text { flow } \\
(n=5)\end{array}$ \\
\hline $\mathrm{CH}_{3} \mathrm{Cl}$ & $\mathbf{1 . 0}$ & $\mathbf{4 0 . 1}$ & $\mathbf{1 1 . 4}$ & $\mathbf{- 1 8 . 1},-\mathbf{5 8 . 3}$ & $\mathbf{2 1 . 3}$ \\
& $(-29.6-69.0)$ & $(-14.2-99.7)$ & $(-14.7-36.6)$ & & $(-13.5-46.2)$ \\
$\mathrm{CH}_{3} \mathrm{Br}$ & $\mathbf{0 . 4}$ & $\mathbf{2 . 7}$ & $\mathbf{1 . 8}$ & $\mathbf{- 0 . 5},-\mathbf{1 . 6}$ & $\mathbf{2 . 1}$ \\
& $(-0.8-3.9)$ & $(0.1-8.3)$ & $(0.2-3.3)$ & & $(0.1-4.4)$ \\
$\mathrm{CH}_{3} \mathrm{I}$ & $\mathbf{0 . 6}$ & $\mathbf{3 . 3}$ & $\mathbf{1 . 6}$ & $\mathbf{0 . 1}, \mathbf{0 . 1}$ & $\mathbf{1 . 5}$ \\
& $(-0.6-2.6)$ & $(0.1-8.0)$ & $(0.1-2.9)$ & & $(0.2-3.0)$ \\
$\mathrm{CHCl}_{3}$ & $\mathbf{0 . 3}$ & $\mathbf{2 . 4}$ & $\mathbf{2 . 0}$ & $\mathbf{- 0 . 1}, \mathbf{- 2 . 0}$ & $\mathbf{2 . 0}$ \\
& $(-0.8-2.8)$ & $(0.1-6.6)$ & $(0.5-3.0)$ & & $(-0.6-3.7)$ \\
$\mathrm{CHBr}_{3}$ & $\mathbf{0 . 4}$ & $\mathbf{2 . 9}$ & $\mathbf{2 . 8}$ & $\mathbf{0 . 5},-\mathbf{0 . 1}$ & $\mathbf{4 . 5}$ \\
& $(-0.5-1.3)$ & $(0.2-10.6)$ & $(0.2-5.1)$ & & $(-0.4-8.6)$ \\
$\mathrm{CS}_{2}$ & $\mathbf{5 2}$ & $\mathbf{2 1 6}$ & $\mathbf{1 3 5}$ & $\mathbf{4 2 0 , 3 9 8}$ & $\mathbf{1 2 9}$ \\
& $(-34-192)$ & $(22-544)$ & $(-5.5-200.0)$ & & $(-13.4-230)$ \\
$\mathrm{Propen}$ & $\mathbf{5 6}$ & $\mathbf{1 6 7}$ & $\mathbf{9 1}$ & $\mathbf{3 3 , 2 7}$ & $\mathbf{1 8 2}$ \\
& $(-26-377)$ & $(91-331)$ & $(-5.1-170)$ & & $(3.4-407)$ \\
\hline
\end{tabular}

our study, the respiratory $\mathrm{CO}_{2}$ fluxes during tidal immersion exceeded the respiratory $\mathrm{CO}_{2}$ flux during air exposure by a factor of 2.4 and the methane fluxes during immersion exceeded those during air exposure by a factor of 2.9.

During measurements carried out in the back barrier area of the island of Spiekeroog (Billerbeck et al., 2006; Jansen et al., 2009), the highest oxygen penetration rates were observed immediately after high tide. In accordance with this, Yamamoto et al. (2009) noted a concurrent increase in the redox potential of the sediment with increasing $\mathrm{CH}_{4}$ and $\mathrm{CO}_{2}$ fluxes during tidal inundation. The $\mathrm{CH}_{4}$ fluxes observed in the Ria Formosa lagoon provide a mirror image of these oxygen dynamics. Given this, we deduce an overall strong effect of advective solute transport at the sediment-water interface on trace gas fluxes to explain the elevated fluxes during tidal immersion. Both the observed similarities between the flux patterns among all trace gases and the relatively constant $\mathrm{CO}_{2} / \mathrm{CH}_{4}$ ratios observed at night-time, when photosynthesis was not interfering with flux patterns, suggest physical forcing as the major driver of trace gas fluxes rather than the biogeochemical processes controlling their formation.

It is commonly thought that the fluxes during air exposure are most likely driven by gas evasion across the sediment-air and plant-air interface and are hence controlled by the transfer resistance across these interfaces (Yamamoto et al., 2009, and references therein). However, this model cannot explain the observed drop to zero of $\mathrm{CO}_{2}$ and $\mathrm{CH}_{4}$ fluxes for about 15 min when the incoming tide reached the sampling site. In waterlogged sediments, trace gases have to be transported to the sites of gas diffusion, such as to a water-gas interface or to the root systems of higher plants. Werner et al. (2006) observed a constant flow velocity of porewater over the entire period of air exposure and noted a decreasing flow velocity in the top $2 \mathrm{~cm}$ shortly before the flood current reached the sampling site and flow direction reversed. Although the chamber will certainly affect the water flow in the top sediment, this may provide a clue to explain the observed drop in the emission fluxes.

The drop in the fluxes was followed by a dramatic peak in both $\mathrm{CO}_{2}$ and $\mathrm{CH}_{4}$ emissions when floodwater reached the chamber. Thereafter, $\mathrm{CH}_{4}$ fluxes dropped, increasing again with tidal height. In contrast, the respiratory $\mathrm{CO}_{2}$ night flux showed a gradual decline. Similar flux peaks with incoming floodwater have been previously reported for biogenic sulfur compounds (Aneja et al., 1986; Cooper et al., 1987a, b) and ammonia (Falcão and Vale, 2003), being attributed to increased hydrodynamic pressure. In contrast to these observations, we did not observe a pronounced peak for any of the VOCs other than $\mathrm{CH}_{4}$. However, it is possible that the peak events were not captured due to our discrete VOC sampling method.

We speculate that the peaks are caused by the sudden release of the air trapped in the sediment pore space that becomes enriched in $\mathrm{CH}_{4}$ and $\mathrm{CO}_{2}$ during air exposure. The release of trapped air from the sediment may be fostered by the aforementioned reversal of flow direction in tidal surface sediments reported by Werner et al. (2006). Such an emission mechanism is further supported by the fact that a similar drop in the $\mathrm{CH}_{4}$ emission is also observed for the change from tidal immersion to air exposure but not followed by an emission peak, which is simply due to the lack of air bubbles in the sediment at this stage of the tidal cycle. Furthermore, the higher fluxes during tidal inundation may impede the enrichment of trace gases in the surface sediment. The short and 
sharp emission peak for $\mathrm{CH}_{4}$ suggests that the $\mathrm{CH}_{4}$ has been accumulated close to the sediment surface or close to the roots of the seagrass, from where it can be readily transferred into the atmosphere. In agreement with this, our data clearly show higher $\mathrm{CH}_{4}$ emission peaks during night-time than daytime, when sediment oxygenation resulting from photosynthesis favours $\mathrm{CH}_{4}$ oxidation.

During night-time, the respiratory $\mathrm{CO}_{2}$ flux and the $\mathrm{CH}_{4}$ flux show a fairly constant ratio during air exposure but evolve differently during tidal immersion. In contrast to the gradual decline of $\mathrm{CO}_{2}$ after the peak at incoming tide, $\mathrm{CH}_{4}$ dropped sharply after this peak, increasing again with tidal height. $\mathrm{CH}_{4}$ originating from deeper sediment layers has a fairly low water solubility and thus becomes strongly enriched in the entrapped gas. Hence, the transition from a bubble ebullition driven emission, as suggested for the " $\mathrm{CH}_{4}$ peak", to an advective transport of porewater, as suggested for the period of tidal immersion, results in a sharp decrease in the $\mathrm{CH}_{4}$ flux. The following increase in $\mathrm{CH}_{4}$ may reflect the increasing penetration depth of the advective flow with the rising water table. $\mathrm{CO}_{2}$ is always close to equilibrium with the much larger porewater DIC pool. After the transition from bubble ebullition to advective transport, the $\mathrm{CO}_{2}$ flux is driven by the exchange of enriched porewater DIC and the observed gradual decline in the $\mathrm{CO}_{2}$ flux reflects the dilution of the porewater with the overlying seawater.

While the seagrass incubations showed a continuous decline of the $\mathrm{CO}_{2}$ flux during tidal immersion, the incubations at the non-vegetated sediment showed a partial recovery of the $\mathrm{CO}_{2}$ flux after high tide and thus an inverse correlation with the height of the water table. As outlined before, this difference may result from the onset of photosynthetic $\mathrm{CO}_{2}$ assimilation at the end of the tidal cycle at sunrise, which had a more pronounced impact within the seagrass incubations.

\subsection{Magnitude of $\mathrm{CH}_{4}$ fluxes}

$\mathrm{CH}_{4}$ emissions of the $\mathrm{Z}$. noltii community averaged $0.31 \mathrm{mmol} \mathrm{m}^{-2} \mathrm{~d}^{-1}$, with $\sim 76 \%$ being released during tidal immersion. These are about 4-fold higher than $\mathrm{CH}_{4}$ fluxes from the non-vegetated sediment community $\left(0.07 \mathrm{mmol} \mathrm{m}^{-2} \mathrm{~d}^{-1}\right.$, with $\sim 93 \%$ being released during tidal immersion). Oremland (1975) reported $\mathrm{CH}_{4}$ production rates ranging from 0.26 to $1.80 \mathrm{mmol} \mathrm{m}^{-2} \mathrm{~d}^{-1}$ from a Thalassia testudinum bed and production rates ranging from 0.08 to $0.19 \mathrm{mmol} \mathrm{m}^{-2} \mathrm{~d}^{-1}$ from a Syringopodium sp. community. In a study of Deborde et al. (2010), the methane production rates in the surface sediments of $Z$. noltii sites were generally below $0.04 \mathrm{mmol}^{-2} \mathrm{~m}^{-2} \mathrm{~d}^{-1}$ (this being the detection limit of their method). In contrast to our results, they observed higher production rates in unvegetated sediments ranging from $<0.04$ to $0.78 \mathrm{mmol} \mathrm{m}^{2} \mathrm{~d}^{-1}$. The average sedimentary $\mathrm{CH}_{4}$ flux of $0.07 \mathrm{mmol} \mathrm{m}^{-2} \mathrm{~d}^{-1}$ in our study is at the lower end of this range.
Bartlett et al. (1987) and Delaune et al. (1983) reported decreasing $\mathrm{CH}_{4}$ fluxes with increasing salinity. $\mathrm{CH}_{4}$ fluxes decreased from 17 to $34.2 \mathrm{mmol} \mathrm{m}^{-2} \mathrm{~d}^{-1}$ at salinities around $1 \mathrm{PSU}$ to 0.17 to $0.85 \mathrm{mmol} \mathrm{m}^{-2} \mathrm{~d}^{-1}$ at salinities above 18 PSU. Our data fell well into the range given for higher salinities, although a direct comparison of these values with our data is difficult due to the differences in salinity. Middelburg et al. (2002) estimated the average $\mathrm{CH}_{4}$ flux from European estuarine waters to be $0.13 \mathrm{mmol} \mathrm{m}^{-2} \mathrm{~d}^{-1}$, which is about twice the fluxes of the non-vegetated sediments of the Ria Formosa lagoon. Hence, our data suggest that, apart from body circulation (Jansen et al., 2009; Grunwald et al., 2009), skin circulation may substantially contribute to $\mathrm{CH}_{4}$ fluxes in tidal flats.

A tentative upscaling using our flux data and a global seagrass coverage area of $300000 \mathrm{~km}^{2}$ (Duarte et al., 2005) reveals a global $\mathrm{CH}_{4}$ flux of $\sim 0.5 \mathrm{Tg} \mathrm{CH}_{4} \mathrm{yr}^{-1}$ from seagrass meadows. With the inclusion of data from Oremland (1975) and Deborde et al. (2010), global emissions may range from $<0.1$ to $2.5 \mathrm{Tg} \mathrm{CH}_{4} \mathrm{yr}^{-1}$. The ocean, including the productive coastal ecosystems, is a minor source of atmospheric $\mathrm{CH}_{4}$, contributing about $10 \%$ to the global sources (Wuebbles and Hayhoe, 2002), with emissions estimated to be in the range of 11 to $18 \mathrm{Tg} \mathrm{yr}^{-1}$ (Bange et al., 1994). Despite the large uncertainty in this estimate, it is reasonable to suppose seagrass meadows being a minor global source of $\mathrm{CH}_{4}$.

\subsection{Magnitude of $\mathrm{CO}_{2}$ fluxes}

Our method may underestimate the $\mathrm{CO}_{2}$ fluxes by $20 \pm 15 \%$ as outlined in the methods section. However, it is worth comparing the results from this study with those from previous studies.

During our experiment, the overall net community production (NCP) of Z. noltii was $101 \mathrm{mmol} \mathrm{C} \mathrm{m}^{-2} \mathrm{~d}^{-1}$ and that of unvegetated sediments was $50 \mathrm{mmol} \mathrm{C} \mathrm{m}^{-2} \mathrm{~d}^{-1}$, showing that heterotrophic metabolism was dominant in the intertidal of Ria Formosa lagoon. Santos et al. (2004) found that the intertidal was marginally autotrophic in July 2002 with a NCP of $-5.5 \mathrm{mmol} \mathrm{C} \mathrm{m} \mathrm{d}^{-2} \mathrm{~d}^{-1}$ for $Z$. noltii and of $-21.2 \mathrm{mmol} \mathrm{C} \mathrm{m}{ }^{-2} \mathrm{~d}^{-1}$ for the unvegetated sediment.

We present here, to the best of our knowledge, the first assessment of how the respiration of a seagrass community varies over night along with the tidal cycle. Several previous studies used punctual measurements, either with dark chambers or during the night, to assess the community respiration (Santos et al., 2004; Silva et al., 2008; Duarte et al., 2010; Clavier et al., 2011). These punctual data were scaled up to estimate daily respiration rates and to calculate daily metabolic budgets of seagrass communities. Our data show that this practice may seriously affect the estimation of the metabolic daily budgets of seagrass communities, particularly in the intertidal. The average net $\mathrm{CO}_{2}$ emissions (community respiration, $\mathrm{CR}$ ) of $\mathrm{Z}$. noltii during night were 10.2 (air exposure), 23.2 (tidal immersion) and 
$55.0 \mathrm{mmol} \mathrm{m}^{-2} \mathrm{~h}^{-1}$ (peak event) (Table 1). With an average daylight period of $12 \mathrm{~h}$ and an average period of tidal inundation of $15.30 \mathrm{~h} \mathrm{~d}^{-1}$, the community respiration is estimated to be $233 \mathrm{mmol} \mathrm{m}^{-2} \mathrm{~d}^{-1}$ during night-time.

The respiratory $\mathrm{CO}_{2}$ production peaks during incoming flood tide are immediately recycled during the day, i.e assimilated by the seagrass community. The observed accelerated decreases in the $\mathrm{CO}_{2}$ flux coinciding with sunrise and the much lower $\mathrm{CO}_{2}$ peaks observed during the day at the transition from air exposure to inundation provide evidence of this. Over the course of the experiment, a net $\mathrm{CO}_{2}$ assimilation occurred roughly between 09:00 and 18:00 UTC, with average net assimilation rates of $9.1 \mathrm{mmol} \mathrm{m}^{-2} \mathrm{~h}^{-1}$ during air exposure and $16.4 \mathrm{mmol} \mathrm{m}^{-2} \mathrm{~h}^{-1}$ during immersion, summing up to a net $\mathrm{CO}_{2}$ assimilation of $125 \mathrm{mmol} \mathrm{m}^{-2} \mathrm{~d}^{-1}$. The NCP of $Z$. noltii during air exposure estimated here compares well to the previously reported rates ranging from 10 to $15 \mathrm{mmol} \mathrm{m}^{-2} \mathrm{~h}^{-1}$ (Silva et al., 2005), whereas NCP during tidal immersion significantly exceeds previously reported rates of less than $5 \mathrm{mmol} \mathrm{m}^{-2} \mathrm{~h}^{-1}$ from the Ria Formosa (Santos et al., 2004; Silva et al., 2005, 2008). These earlier studies used static chambers, which are prone to introduce stagnant conditions. In contrast, the bubbling in our chamber introduces turbulent mixing and hence may facilitate the transport of $\mathrm{CO}_{2}$ across the water-leaf interface. Thus, these differences can be mainly attributed to the introduction of advection in our chamber system. In accordance with our results, Clavier et al. (2011) recently reported a higher NCP during submersion than under aerial conditions from a Z. noltii bed in the Banc d'Arguin (Mauritania). A benthic chamber equipped with submersible pumps to maintain a turbulent water flow during submersion was used in the study. They found a NCP of about $3 \mathrm{mmol} \mathrm{m}^{-2} \mathrm{~h}^{-1}$ under aerial conditions and about $20 \mathrm{mmol} \mathrm{m}^{-1} \mathrm{~h}^{-1}$ under submerged conditions, with the latter being derived from DIC and oxygen measurements. The respective gross primary production rates in the study of Clavier et al. (2011) were 6 and $42.7 \mathrm{mmol} \mathrm{m}^{-2} \mathrm{~h}^{-1}$. From our $\mathrm{CO}_{2}$ flux measurements we estimated a net community production of $9.1 \mathrm{mmol} \mathrm{m}^{-2} \mathrm{~h}^{-1}$ under aerial conditions and of $16.4 \mathrm{mmol} \mathrm{m}^{-2} \mathrm{~h}^{-1}$ under submerged conditions. To make a first rough estimate of the gross community production in our study, we can simply add the observed respiration fluxes measured during night to the net community production, resulting in an estimated gross community production of $17.5 \mathrm{mmol} \mathrm{m}^{-2} \mathrm{~h}^{-1}$ under aerial conditions and of $36.5 \mathrm{mmol} \mathrm{m}^{-2} \mathrm{~h}^{-1}$ under submerged conditions; however the peak occurring at the transition from air exposure to immersion has not been included. The net and gross community production rates from both studies agree quite well, in particular under submerged conditions, while our production rates under aerial conditions were about 3 times higher than those reported in Clavier et al. (2012). When including the carbon evolution from the sediment, we can estimate a gross primary production of $4.3 \mathrm{~g} \mathrm{C} \mathrm{m}^{-2} \mathrm{~d}^{-1}$, which is close to the $\sim 5 \mathrm{~g} \mathrm{C} \mathrm{m}^{-2} \mathrm{~d}^{-1}$ computed from changes in the living biomass by Cabaço et al. (2012) for established meadows of Z. noltii in the Ria Formosa for this time (late spring) of the year. In this context it should be noted that the available data on the aerial versus submerged photosynthesis of Z. noltii are not consistent, as already outlined in Silva et al. (2005). While Leuschner and Rees (1993) and Leuschner et al. (1998) measured comparable rates of $\mathrm{CO}_{2}$ assimilation in air and water, Perez-Llorens and Niell (1994) found $\mathrm{CO}_{2}$ uptake rates in air 10 to 20 times lower than in water. We currently cannot appraise the quality and reliability of the different chamber systems as the strength of advection in our chamber system relative to ambient conditions is unknown. However, these differences highlight the importance of accurately addressing the perturbations of turbulent flows in benthic flux chambers.

\subsection{VOCs}

The overall focus of this section is the temporal evolution of the VOC fluxes over a tidal cycle. A quantitative discussion of the VOC data and an assessment of potential intrinsic sources are beyond the scope of this paper. For the halocarbons, this will be done elsewhere (Weinberg et al., 2015). $\mathrm{CS}_{2}$, which has a known sedimentary source (Bodenbender et al., 1999), shows a similar temporal pattern to $\mathrm{CH}_{4}$ during high tide. Thus, we conclude that the emission of $\mathrm{CS}_{2}$ is, in analogy to $\mathrm{CH}_{4}$, mainly controlled by advective transport across the sediment-water interface.

Halocarbon production in the marine environment is generally attributed to photoautotrophic sources (Gschwend et al., 1985; Manley et al., 2006; Moore et al., 1995), though there is some evidence of a sedimentary bacterial source of iodomethane (Amachi et al., 2001). In seagrass meadows, halocarbons are presumably produced by the seagrass or the microphytobenthos. Only in the latter case can porewater flow across the sedimentary interface directly affect the emission. However, the elevated halocarbon fluxes during tidal immersion may reflect an enhanced transport across the leaf-water interface and/or result from the enhanced net primary production during immersion. Sediments may also act as a sink for monohalomethanes (Miller et al., 2001; Bill et al., 2002), and trihalomethanes are known to be degraded by a variety of microorganisms (Alasdair and Allard, 2008). Hence, the remarkable decrease and the uptake of the halocarbons may simply reflect sedimentary degradation processes. We further noted remarkable levels of $\mathrm{H}_{2} \mathrm{~S}$ and methanethiol in our samples during high tide. In particular, $\mathrm{H}_{2} \mathrm{~S}$ is a very reactive nucleophile, readily reacting with monohalomethanes (Barbash and Reinhard, 1989), and thus may additionally foster their degradation. In summary, similar to $\mathrm{CH}_{4}$ and $\mathrm{CO}_{2}$, the VOC fluxes are more pronounced during tidal immersion than during air exposure but further show some differences resulting from their different sources and sinks. 


\section{Conclusions}

We have presented flux measurements for a variety of trace gases in a tidally influenced seagrass bed $(Z$. noltii) using a newly developed dynamic flux chamber system that can be deployed over full tidal cycles. An unambiguous quantification of carbon fluxes in future studies requires additional measures such as $\mathrm{pH}$ or alkalinity to better constrain the carbonate system. Further, the water exchange between the chamber and surrounding waters should be quantified. Despite these caveats, our results provide new insights into the temporal flux dynamics. In particular, the $\mathrm{CO}_{2}$ and $\mathrm{CH}_{4}$ data illustrate the need for high-time-resolution measurements to accurately address the fluxes and dynamics of trace gases in tidally controlled systems. We observed short emission peaks with the flood current arriving at the sampling site for $\mathrm{CH}_{4}$. In line with previous studies that have demonstrated the importance of advective transport processes for the oxygenation of sediments, our results show a general strong control of advective transport processes on trace gas fluxes in intertidal systems during submersion. We are aware of only very few earlier studies of intertidal systems indicating elevated fluxes during tidal immersion or periods of tidal change. In contrast to most previous flux chamber studies, our data indicate significant enhanced fluxes during tidal immersion relative to periods of air exposure for all trace gases measured. Similar results have been previously reported for oxygen, DIC nutrients and suspended matter. Hence, our results highlight the importance of accurately addressing the perturbations of turbulent flows in flux chamber studies. If the observed flux enhancements are more than just episodic events, this may have fundamental implications for our understanding of the carbon and trace gas cycling in coastal environments.

\section{The Supplement related to this article is available online at doi:10.5194/bg-12-1683-2015-supplement.}

Acknowledgements. The authors thank the German Federal Ministry of Education and Research (BMBF) for funding (grants 03F0611E and 03F0662E). This work was partly supported by the EU FP7 ASSEMBLE research infrastructure initiative and the project "Whole-system metabolism and $\mathrm{CO}_{2}$ fluxes in a coastal lagoon dominated by saltmarsh and seagrass meadows", PTDC/AAC-CLI/103348/2008. João Reis and Bruno Fragoso (CCMAR, Universidade do Algarve) are greatly acknowledged for their extensive support during sampling site selection and sampling. Our technical staff members Sabine Beckmann and Ralf Lendt are thanked for their invaluable help.

Edited by: J.-A. Subke

\section{References}

Alasdair H. N. and Allard A.-S.: Environmental degradation and transformation of organic chemicals, CRC Press, Boca Raton, 2008.

Amachi, S., Kamagata, Y., Kanagawa, T., and Muramatsu, Y.: Bacteria mediate methylation of iodine in marine and terrestrial environments, Appl. Environ. Microb., 67, 2718-2722, 2001.

Aneja, V. P.: Characterization of emissions of biogenic hydrogen sulfide, Tellus B, 38, 81-86, 1986.

Armstrong, W.: Aeration in higher plants, Adv. Botanical Res., 7, 225-332, 1979.

Bahlmann, E., Weinberg, I., Seifert, R., Tubbesing, C., and Michaelis, W.: A high volume sampling system for isotope determination of volatile halocarbons and hydrocarbons, Atmos. Meas. Tech., 4, 2073-2086, doi:10.5194/amt-4-2073-2011, 2011.

Baird, A. J., Beckwith, C. W., Waldron, S., and Waddington, J. M.: Ebullition of methane-containing gas bubbles from nearsurface Sphagnum peat, Geophys. Res. Lett., 31, L21505, doi:10.1029/2004GL021157, 2004

Baker, J. M., Reeves, C. E., Nightingale, P. D., Penkett, S. A., Gibb, S. W., and Hatton, A. D.: Biological production of methyl bromide in the coastal waters of the North Sea and open ocean of the northeast Atlantic, Mar. Chem., 64, 267-285, 1999.

Bange, H. W., Bartell, U. H., Rapsomanikis, S., and Andreae, M. O.: Methane in the Baltic and North Seas and a reassessment of the marine emissions of methane, Global Biogeochem. Cy., 8, 465-480, 1994.

Barbash, J. E. and Reinhard, M.: Reactivity of sulfur Nucleophiles toward halogenated organic compounds in natural waters, in Biogenic Sulfur in the Environment, edited by: Saltzman, E. and Cooper, W. J., American Chemical Society, Washington DC, 101-137, 1989.

Barnes, J., Ramesh, R., Purvaja, R., Rajkumar, A. N., Kumar, B. S., Krithika, K., Ravichandran, K., Uher, G., and Upstill-Goddard, R.: Tidal dynamics and rainfall control $\mathrm{N}_{2} \mathrm{O}$ and $\mathrm{CH}_{4}$ emissions from a pristine mangrove creek, Geophys. Res. Lett., 33, L15405, doi:10.1029/2006GL026829, 2006.

Barron, C., Duarte, C. M., Frankignoulle, M., and Borges, A. V.: Organic carbon metabolism and carbonate dynamics in a Mediterranean seagrass (Posidonia oceanica) meadow, Est. Coast., 29 , 417-426, 2006.

Bartlett, K. B., Bartlett, D. S., Harriss, R. C., and Sebacher, D. I.: Methane emissions along a salt-marsh salinity gradient, Biogeochemistry, 4, 183-202, 1987.

Bates, T. S., Lamb, B. K., Guenther, A., Dignon, J., and Stoiber, R. E.: Sulfur emissions to the atmosphere from natural sources, J. Atmos. Chem., 14, 315-337, 1992.

Bill, M., Rhew, R. C., Weiss, R. F., and Goldstein, A. H.: Carbon isotope ratios of methyl bromide and methyl chloride emitted from a coastal salt marsh, Geophys. Res. Lett., 29, 1045 , doi:10.1029/2001gl012946, 2002.

Billerbeck, M., Werner, U., Bosselmann, K., Walpersdorf, E., and Huettel, M.: Nutrient release from an exposed intertidal sand flat, Mar. Ecol. Prog. Ser., 316, 35-51, 2006 a.

Billerbeck, M., Werner, U., Polerecky, L., Walpersdorf, E., deBeer, D., and Huettel, M.: Surficial and deep pore water circulation governs spatial and temporal scales of nutrient recycling in in- 
tertidal sand flat sediment, Mar. Ecol. Prog. Ser., 326, 61-76, 2006b.

Bodenbender, J., Wassmann, R. Papen, H., and Rennenberg, H.: Temporal and spatial variation of sulfur-gas-transfer between coastal marine sediments and the atmosphere, Atmos. Environ., 33, 3487-3502, 1999.

Borum, J., Sand-Jensen, K., Binzer, T., Pedersen, O., and Greve, T.: Oxygen Movement in Seagrasses, Seagrasses: Biology, ecology and conservation, Springer Netherlands, 255-270, 2006.

Brito, A., Newton, A., Tett, P., and Fernandes, T. F.: Sediment and water nutrients and microalgae in a coastal shallow lagoon, Ria Formosa (Portugal): Implications for the Water Framework Directive, J. Environmen. Monit., 12, 318-328, 2010.

Brotas, V., Amorimferreira, A., Vale, C., and Catarino, F.: Oxygen profiles in intertidal sediments of Ria Formosa (S Portugal), Hydrobiologia, 207, 123-129, 1990.

Cabaço, S., Machás, R., Vieira, V., and Santos, R.: Impacts of urban wastewater discharge on seagrass meadows (Zostera noltii), Est. Coast. Shelf Sci., 78, 1-13, 2008.

Chanton, J. P., Martens, C. S., and Kelley, C. A.: Gas-transport from methane-saturated, tidal fresh-water and wetland sediments, Limnol. Oceanogr., 34, 807-819, 1989.

Charpy-Roubaud, C. and Sournia, A.: The comparative estimation of phytoplanktonic microphytobenthic and macrophytobenthic primary production in the oceans, Mar. Microb. Food Web., 4, 31-58, 1990.

Christof, O., Seifert, R., and Michaelis, W.: Volatile halogenated organic compounds in European estuaries, Biogeochemistry, 59, 143-160, 2002.

Cook, P. L. M., Wenzhöfer, F., Glud, R. N., Jansen, F., and Huettel, M.: Benthic solute exchange and carbon mineralization in two shallow subtidal sandy sediments: Effect of advective pore-water exchange, Limnol. Oceanogr., 52, 1943-1963, 2007.

Cooper, D. J., Demello, W. Z., Cooper, W. J., Zika, R. G., Saltzman, E. S., Prospero, J. M., and Savoie, D. L.: Short-term variability in biogenic sulfur emissions from a Florida Spartina alterniflora marsh, Atmos. Environ., 21, 7-12, 1987a.

Cooper, W. J., Cooper, D. J., Saltzman, E. S., Demello, W. Z., Savoie, D. L., Zika, R. G., and Prospero, J. M.: Emissions of biogenic sulfur-compounds from several wetland soils in Florida, Atmos. Environ., 21, 1491-1495, 1987 b.

Dacey, J. W. H., King, G. M., and Wakeham, S. G.: Factors controlling emission of dimethyldulfide from salt marshes, Nature, 330, 643-645, 1987.

Deborde, F., Anschutz, P., Guèrin, F, Porier, D, Marty, D.,Boucher, G., Thouzeau, G., Canto, M., and Abril, G.: Methane sources, sinks and fluxes in a temperate tidal lagoon: The Arcachon Lagoon (SW France), Estuarine, Coast. Shelf Sci., 89, 256-266, 2010.

de la Paz, M., Gomez-Parra, A., and Forja, J.: Variability of the partial pressure of $\mathrm{CO}_{2}$ on a daily-to-seasonal time scale in a shallow coastal system affected by intensive aquaculture activities (Bay of Cadiz, SW Iberian Peninsula), Mar. Chem., 110, 195-204, 2008.

Delaune, R. D., Smith, C. J., and Patrick, W. H.: Methane release from gulf-coast wetlands, Tellus B, 35, 8-15, 1983.

Demello, W. Z., Cooper, D. J., Cooper, W. J., Saltzman, E. S., Zika, R. G., Savoie, D. L., and Prospero, J. M.: Spatial and diel variability in the emissions of some biogenic sulfur-compounds from a Florida Spartina-alterniflora coastal zone, Atmos. Environ., 21, 987-990, 1987.

Ding, W. X., Cai, Z. C., and Tsuruta, H.: Methane concentration and emission as affected by methane transport capacity of plants in freshwater marsh, Water Air Soil Pollut., 158, 99-111, 2004.

Duarte, C. M., Middelburg, J. J., and Caraco, N.: Major role of marine vegetation on the oceanic carbon cycle, Biogeosciences, 2, 1-8, doi:10.5194/bg-2-1-2005, 2005.

Duarte, C. M., Marba, N., Gacia, E., Fourqurean, J. W., Beggins, J., Barron, C., and Apostolaki, E. T.: Seagrass community metabolism: assessing the carbon sink capacity of seagrass meadows. Global. Biogeochem. Cy., 24, GB4032, doi:10.1029/2010GB003793, 2010.

Ferron, S., Alonso-Perez, S. F., Ortega, T., and Forja, J. M.: Benthic respiration on the north- eastern shelf of the Gulf of Cadiz (SW Iberian Peninsula), Mar. Ecol. Prog. Ser., 392, 69-80, 2009.

Gao, F. and Yates, S. R.: Laboratory study of closed and dynamic flux chambers: Experimental results and implications for field application, J. Geophys. Res.-Atmos., 103, 26115-26125, 1998.

Gao, F., Yates, S. R., Yates, M. V., Gan, J. Y., and Ernst, F. F.: Design, fabrication, and application of a dynamic chamber for measuring gas emissions from soil, Environ. Sci. Technol., 31, 148-153, 1997.

Glaser, P. H., Chanton, J. P., Morin, P., Rosenberry, D. mO., Siegel, D. I., Ruud, O., Chasar, L. I., and Reeve, A. S.: Surface deformations as indicators of deep ebullition fluxes in a large northern peatland, Global Biogeochem. Cy., 18, GB1003, doi:10.1029/2003GB002069, 2004.

Grunwald, M., Dellwig, O., Beck, M., Dippner, J. W., Freund, J. A., Kohlmeier, C., Schnetger, B., and Brumsack, H.-J.: Methane in the southern North Sea: sources, spatial distribution and budgets. Estuarine, Coast. Shelf Sci., 81, 445-456, 2009.

Gschwend, P. M., Macfarlane, J. K., and Newman, K. A.: Volatile halogenated organic-compounds released to seawater from temperate marine macroalgae, Science, 227, 1033-1035, 1985.

Guimarães, H., Cunha, A.H., Nzinga, R., and Marques, J.: The distribution of seagrass (Zostera noltii Hornem.) in the Ria Formosa lagoon system and the implications of clam farming on its conservation, J. Nat. Conserv., 20, 30-40, 2012.

Hemminga, M. and Duarte, C. M.: Seagrass ecology, Cambridge, 2000.

Heyer, J. and Berger, U.: Methane emission from the coastal area in the southern Baltic Sea, Estuar. Coast. Shelf Sci., 51, 13-30, 2000.

Hubas, C., Davoult, D., Cariou, T., and Artigas, L. F.: Factors controlling benthic metabolism during low tide along a granulometric gradient in an intertidal bay (Roscoff Aber Bay, France), Mar. Ecol. Prog. Ser., 316, 53-68, 2006.

Huettel, M. and Rusch, A.: Transport and degradation of phytoplankton in permeable sediment, Limnol. Oceanogr., 45, 534549, 2000.

Huettel, M., Ziebis, W., and Forster, S.: Flow-induced uptake of particulate matter in permeable sediments, Limnol. Oceanogr., 41, 309-322, 1996.

Jansen, S., Walpersdorf, E., Werner, U., Billerbeck, M., Böttcher, M. E., and de Beer, D.: Functioning of intertidal flats inferred from temporal and spatial dynamics of $\mathrm{O}_{2}, \mathrm{H}_{2} \mathrm{~S}$ and $\mathrm{pH}$ in their surface sediment, Oc. Dynam., 59, 317-332, 2009. 
Jonkers, H. M., van Bergeijk, S. A., and van Gemerden, H.: Microbial production and consumption of dimethyl sulfide (DMS) in a sea grass (Zostera noltii)-dominated marine intertidal sediment ecosystem (Bassin d'Arcachon, France), Fems Microbiol. Ecol., 31, 163-172, 2000.

Jorgensen, B. B. and Okholmhansen, B.: Emissions of biogenic sulfur gases from a danish estuary, Atmos. Environ., 19, 1737-1749, 1985.

Khalil, M. A. K. and Rasmussen, R. A.: Global sources, lifetimes and mass balances of carbonyl sulfide (OCS) and cabon-disulfide (CS2) in the earths atmosphere, Atmos. Environ., 18, 1805-1813, 1984.

Kim, K. H. and Kim, D.: Seasonal and spatial variability of sediment oxygen fluxes in the Beobsan intertidal flat of Taean Bay, mid-western Korean Peninsula, Geosci. J., 11, 323-329, 2007.

Kim, K. H. and Lindberg, S. E.: Design and initial tests of a dynamic enclosure chamber for measurements of vapor-phase mercury fluxes over soils, Water Air Soil Pollut., 80, 1059-1068, 1995.

Koch, E., Ackerman, J., Verduin, J., and Keulen, M.: Fluid Dynamics in Seagrass Ecology-from Molecules to Ecosystems, Seagrasses: Biology, Ecol. Conservat., Springer Netherlands, 193225, 2006

Koch, E. W.: Preliminary evidence on the interdependent effect of currents and porewater geochemistry on Thalassia testudinum Banks ex Konig seedlings, Aquat. Bot., 63, 95-102, 1999.

Laanbroek, H. J.: Methane emission from natural wetlands: interplay between emergent macrophytes and soil microbial processes, A mini-review, Ann. Bot., 105, 141-153, 2010.

Larkum, A. W. D., Roberts, G., Kuo, J. S., and Strother, S.: Gaseous movement in seagrasses. In: Larkum AWD, McComb AJ and Shepherd SA, Biology of Seagrasses, Elsevier, Amsterdam, 686$722,1989$.

Larned, S.T.: Effects of the invasive, nonindigenous seagrass Zostera japonica on nutrient fluxes between the water column and benthos in a NE Pacific estuary, Mar. Ecol. Prog. Ser., 254, 69-80, 2003.

Leck, C. and Rodhe, H.: Emissions of marine biogenic sulfur to the atmosphere of Northern Europe, J. Atmos. Chem., 12, 63-86, 1991.

Leuschner, C., Landwehr, S., and Mehlig, U.: Limitation of carbon assimilation of intertidal Zostera noltii and Z-marina by desiccation at low tide, Aquat. Bot., 62, 171-176, 1998.

Leuschner, C. and Rees, U.: $\mathrm{CO}_{2}$ gas-exchange of 2 intertidal seagrass species, Zostera-marina $\mathrm{L}$ and Zostera noltii Hornem during emersion, Aquat. Bot., 5, 53-62, 1993.

Lopez, N. I. and Duarte, C. M.: Dimethyl sulfoxide (DMSO) reduction potential in mediterranean seagrass (Posidonia oceanica) sediments, J. Sea Res., 51, 11-20, 2004.

Manley, S. L., Wang, N.-Y., Walser, M. L., and Cicerone, R. J.: Coastal salt marshes as global methyl halide sources from determinations of intrinsic production by marsh plants, Global Biogeochem. Cy., 20, GB3015, doi:10.1029/2005GB002578, 2006.

Martens, C. S. and Berner, R. A.: Methane production in interstitial waters of sulfate-depleted marine sediments, Science 185, $1167-$ 1169, 1974.

Mateo, M., Cebrián, J., Dunton, K., and Mutchler, T.: Carbon Flux in Seagrass Ecosystems, Seagrasses: Biology, Ecology and Conservation, Springer Netherlands, 159-192, 2006.
Meixner, F. X., Fickinger, T., Marufu, L., Serca, D., Nathaus, F. J., Makina, E., Mukurumbira, L., and Andreae, M. O.: Preliminary results on nitric oxide emission from a southern African savanna ecosystem, Nutr. Cy. Agroecosys., 48, 123-138, 1997.

Meysman, F. J. R., Galaktionov, E. S., Gribsholt, B., and Middelburg, J. J.: Bioirrigation in permeable sediments: Advective pore-water transport induced by burrow ventilation, Limnol. Oceanogr., 51, 142-156, 2006.

Middelburg, J. J., Nieuwenhuize, J., Iversen, N., Hogh, N., De Wilde, H., Helder, W., Seifert, R., and Christof, O.: Methane distribution in European tidal estuaries, Biogeochemistry, 59, 95119, 2002.

Migne, A., Davoult, D., Spilmont, N., Menu, D., Boucher, G., Gattuso, J. P., and Rybarczyk, H.: A closed-chamber CO2-flux method for estimating intertidal primary production and respiration under emersed conditions, Mar. Biol., 140, 865-869, 2002.

Migne, A., Spilmont, N., and Davoult, D.: In situ measurements of benthic primary production during emersion: seasonal variations and annual production in the Bay of Somme (eastern English Channel, France), Continent. Shelf Res., 24, 1437-1449, 2004.

Miller, L. G., Kalin, R. M., McCauley, S. E., Hamilton, D. J. T., Harper, G. B., Millet, D. B., Oremland, R. S., and Goldstein A. H.: Large carbon isotope fractionation associated with oxidation of methyl halides by methylotrophic bacteria, Proc. Natl. Acad. Sci. USA, 98, 5833-5837, 2001.

Moore, R. M., Tokarczyk, R., Tait, V. K., Poulin, M., and Geen, C.: Marine phytoplankton as a natural source of volatile organohalogens, in: Grimvall, A. and Leer, E. B., Naturally-Produced Organohalogens, Springer Netherlands, 283-294, 1995.

Newton, A., Icely, J. D., Falcao, M., Nobre, A., Nunes, J. P., Ferreira, J. G., and Vale, C.: Evaluation of eutrophication in the Ria Formosa coastal lagoon, Portugal, Continent. Shelf Res., 23, 1945-1961, 2003.

Nicholson, G. J., Longmore, A. R., and Berelson, W. M.: Nutrient fluxes measured by two types of benthic chamber, Mar. Freshwater Res., 50, 567-572, 1999.

Nielsen, P.: Tidal dynamics of the water-table in beaches, Water Resour. Res., 26, 2127-2134, 1990.

Oremland, R. S.: Methane production in shallow-water, tropical marine sediments, Appl. Microbiol., 30, 602-608, 1975.

Oremland, R. S., Marsh, L. M., and Polcin, S.: Methane production and simultaneous sulfate reduction in anoxic, salt-marsh sediments, Nature, 296, 143-145, 1982.

Ouisse, V., Migne, A., and Davoult, D.: Community-level carbon flux variability over a tidal cycle in Zostera marina and Z-noltii beds, Mar. Ecol. Prog. Ser., 437, 79-87, 2011.

Pape, L., Ammann, C., Nyfeler-Brunner, A., Spirig, C., Hens, K., and Meixner, F. X.: An automated dynamic chamber system for surface exchange measurement of non-reactive and reactive trace gases of grassland ecosystems, Biogeosciences, 6, 405429, doi:10.5194/bg-6-405-2009, 2009.

Pérez-Llorens, J. L. and Niell, F. X.: Photosynthesis in air: comparative responses to different temperatures of two morphotypes of Zostera noltii Hornem. from Palmones River estuary (southern Spain), Verh. Internat. Verein, Limnol. Oceanogr., 25, 22652269, 1994.

Precht, E. and Huettel, M.: Advective pore-water exchange driven by surface gravity waves and its ecological implications, Limnol. Oceanogr., 48, 1674-1684, 2003. 
Precht, E. and Huettel, M.: Rapid wave-driven advective pore water exchange in a permeable coastal sediment, J. Sea Res., 51, 93107, 2004.

Rhew, R. C., Miller, B. R., and Weiss, R. F.: Natural methyl bromide and methyl chloride emissions from coastal salt marshes, Nature, 403, 292-295, 2000.

Riedl, R. J., Machan, R., and Huang, N.: Subtidal pump - mechanisms of interstitial water exchange by wave action, Mar. Biol., 13, 210-221, 1972.

Santos, R., Silva, J., Alexandre, A., Navarro, N., Barron, C., and Duarte, C. M.: Ecosystem metabolism and carbon fluxes of a tidally-dominated coastal lagoon, Estuaries, 27, 977-985, 2004.

Sebacher, D. I., Harriss, R. C., and Bartlett, K. B.: Methane emissions to the atmosphere through aquatic plants, J. Environ. Qual., 14, 40-46, 1985.

Silva, J., Feijoo, P., and Santos, R.: Underwater measurements of carbon dioxide evolution in marine plant communities: A new method, Estuar. Coast. Shelf Sci., 78, 827-830, 2008.

Silva, J., Santos, R., Calleja, M. L., and Duarte, C. M.: Submerged versus air-exposed intertidal macrophyte productivity: from physiological to community-level assessments, J. Experimen. Mar. Biol. Ecol., 317, 87-95, 2005.

Spilmont, N., Migne, A., Lefebvre, A., Artigas, L. F., Rauch, M., and Davoult, D.: Temporal variability of intertidal benthic metabolism under emersed conditions in an exposed sandy beach (Wimereux, eastern English Channel, France), J. Sea Res., 53, 161-167, 2005.

Tengberg, A., Stahl H., G. Gust, G., V. Mueller, V., U. Arning, U., Andersson, H., and Hall, P. A. J.: Intercalibration of benthic flux chambers I. Accuracy of flux measurements and influence of chamber hydrodynamics, Prog. Oceanogr., 60, 1-28, 2004.

Thibodeaux, L. J. and Boyle, J. D.: Bedform-generated convectivetransport in bottom sediment, Nature, 325, 341-343, 1987.
Turner, S. M., Malin, G., and Liss, P. S.: Dimethyl Sulfide and (Dimethylsulfonio) propionate in European Coastal and Shelf Waters, Biogenic Sulfur in the Environment, Am. Chem. Soc., 183-200, 1989.

Urhahn, T.: Leichtflüchtige ECD-aktive Verbindungen in der marinen Grundschicht (MBL) des Atlantischen Ozeans: Vorkommen, Quellen und Verteilung, Department of Analytical Chemistry and Environmental Chemistry, University of Ulm, Ulm, Germany, 2003.

Valtanen, A., Solloch, S., Hartikainen, H., and Michaelis, W.: Emissions of volatile halogenated compounds from a meadow in a coastal area of the Baltic Sea, Bor. Environ. Res., 14, 915-931, 2009.

Van der Nat, F. J. and Middelburg, J. J.: Methane emission from tidal freshwater marshes, Biogeochemistry, 49, 103-121, 2000.

Werner, U., Billerbeck, M., Polerecky, L., Franke, U., Huettel, M., van Beusekom, J. E. E., and de Beer, D.: Spatial and temporal patterns of mineralization rates and oxygen distribution in a permeable intertidal sand flat (Sylt, Germany), Limnol. Oceanogr., 51, 2549-2563, 2006.

Wuebbles, D. J. and Hayhoe, K.: Atmospheric methane and global change, Earth-Sci. Rev., 57, 177-210, 2002.

Yamamoto, A., Hirota, M., Suzuki, S., Oe, Y., Zhang, P., and Mariko, S.: Effects of tidal fluctuations on $\mathrm{CO}_{2}$ and $\mathrm{CH}_{4}$ fluxes in the littoral zone of a brackish-water lake, Limnology, 10, 228237, 2009.

Zhang, H., Lindberg, S. E., Barnett, M. O., Vette, A. F., and Gustin, M. S.: Dynamic flux chamber measurement of gaseous mercury emission fluxes over soils, Part 1: simulation of gaseous mercury emissions from soils using a two-resistance exchange interface model, Atmos. Environ., 36, 835-846, 2002. 